\title{
Pulmonary function in asbestos cement workers: a dose-response study
}

\author{
M FINKELSTEIN
}

From the Health Studies Service, Ontario Ministry of Labour, Toronto, Ontario M7A 1T7, Canada

ABSTRACT This study has found that residence time weighted exposure (asbestos dose) may be used to model the risk and extent of pulmonary function abnormalities in a cohort of asbestos cement workers. This parameter, which incorporates both exposure concentration and latency, had previously proved useful for modelling the risk of radiographic abnormalities in this cohort. Asbestos dose and smoking were independent and additive contributors to decreased pulmonary function. It was also found that lung function results could be used as surrogates for dose in the assessment of mortality risk in this cohort.

In a previous paper it was noted that asbestos disease may develop or progress after exposure has ceased, and that the usual measure of exposure, the "cumulative exposure," suffers from the shortcoming that its value remains fixed once exposure has ended, requiring that both cumulative exposure and time enter explicitly into risk assessment. ${ }^{1}$ It was shown that an alternative measure called "dose" (which is the sum of the annual asbestos exposure weighted by the retention time) could be used to model the risk of certain radiographic abnormalities in a cohort of asbestos cement workers, and that when using this measure, the assessment of risk had the desirable property of being independent of the time of evaluation over the interval $20-34$ years from first exposure.

The present study was performed to assess whether "dose" might also be useful in describing the development of pulmonary function abnormalities in this cohort. This measure was found to provide descriptions of the relations between exposure to asbestos and physiological abnormality that were independent of the time of assessment, and it is concluded that dose- that is, the residence time weighted exposuremight be generally useful in describing the relations between exposure to fibrogenic dusts and the risk of disease.

\section{Materials and methods}

STUDY POPULATION

Men eligible for inclusion in the study were production workers hired before 1960 who had been emAccepted 4 November 1985 ployed for nine years or more and who had worked at least 12 months in occupations with exposure to as- ${ }^{\circ}$ bestos. When six men who had died before the start of $\ddot{\odot}$ pulmonary function testing in 1970 were excluded, $\odot$ 180 men met the criteria for inclusion; of these, 138 응 $(77 \%)$ had at least one set of measurements available. Many had been tested several times and 52 had been $\bar{\partial}$ tested on ten or more occasions.

Table 1 gives the numbers of men who had mea- $\stackrel{\circ}{\perp}$ surements at various intervals from first exposure $\stackrel{2}{\overrightarrow{0}}$ (latency). After analysis had indicated that the dose- $\frac{0}{3}$ response pattern was independent of latency a "master" cohort was assembled by selecting one set of measurements from each of the 138 men. The demography of this master cohort is also given in table 1 .

EXPOSURE AND DOSE ESTIMATION

Information about the factory and the estimation of individual exposures by extrapolation from personal membrane filter measurements has been published. ${ }^{2}$ 은 Asbestos dosages were calculated by assuming that $a \frac{D}{0}$ fixed proportion of the workplace air concentrations was deposited in the lungs and each year's accumu- $N$ lation was weighted by the residence time in lung tis- $N$ sue (the formula used is given in the appendix). The $\sim$ units for dose are fibres $/ \mathrm{ml} \times$ years squared $\omega$ $\left(\mathrm{f} / \mathrm{ml} \times \mathrm{y}^{2}\right)$.

Cumulative exposures had previously been esti- 0 mated to be accurate to within a factor of three to $\Phi$ five $^{2}$; since the formula used to calculate dose weights $\stackrel{?}{?}$ early exposures most heavily, the dose estimates used $\frac{0}{0}$ here are probably more uncertain than the estimates $\frac{\text { Oे }}{\mathbb{D}}$ of cumulative exposure. 
Table 1 Study population

\begin{tabular}{|c|c|c|}
\hline & & No of men \\
\hline \multicolumn{3}{|l|}{ Latency analysis } \\
\hline \multicolumn{3}{|l|}{ Latency interval: } \\
\hline 20-24 years & & 115 \\
\hline $25-29$ years & & 103 \\
\hline $30-34$ years & & 46 \\
\hline \multirow{2}{*}{\multicolumn{3}{|c|}{$\begin{array}{l}\text { Master conort } \\
\text { Latency interval: }\end{array}$}} \\
\hline & & \\
\hline $15-19$ years & & 7 \\
\hline 20-24 years & & 41 \\
\hline $\begin{array}{l}25-29 \text { years } \\
30-34 \text { years }\end{array}$ & & $\begin{array}{l}60 \\
30\end{array}$ \\
\hline Mean age: 58 & Range 33-78 & Standard deviation 8.5 \\
\hline $\begin{array}{l}\text { Mean height: } 174 \mathrm{~cm} \\
\text { Smokers: } \mathrm{n}=95\end{array}$ & $\begin{array}{l}\text { Range: } 156-189 \\
\text { Non-smokers: } n=43\end{array}$ & Standard deviation $6 \cdot 1$ \\
\hline Smokers: n = 95 & Non-smokers: $\mathrm{n}=43$ & \\
\hline
\end{tabular}

\section{SMOKING INFORMATION}

Smoking information had been requested by pulmonary function technicians at the time of examination. Additional information was obtained by questionnaire and from physicians' records. For the purposes of this study, smokers were defined as men who had smoked cigarettes later than 10 years from first exposure; non-smokers were defined as men who had never smoked or who had stopped before 10 years from first exposure. For most of the analyses in this paper, smoking was treated as a dichotomous variable.

\section{PULMONARY FUNCTION TESTING (PFT)}

All measurements were made either as part of routine surveillance of the workforce or as part of the assessment for workers' compensation claims; none was made specifically for epidemiological purposes. A mobile laboratory from the Occupational Chest Disease Service of the Ontario Ministry of Labour made biannual visits to the plant and performed a standard spirometric evaluation yielding values for forced vital capacity (FVC) and forced expiratory volume in the first second of expiration $\left(F E V_{1}\right)$. All volumes were corrected to BTPS. Compensation examinations were performed in the laboratory of the Chest Disease Service and a more elaborate assessment, including the measurement of static lung volumes and exercise testing, was performed. In addition to FVC and $F E_{1}$ the tests selected for analysis in this study include total lung capacity (TLC), the single breath carbon monoxide diffusing capacity (uncorrected for haemoglobin concentration) (DLCO), and DLCO per unit lung volume $(\mathrm{KCO})$.

The reference equations of Knudson et al and Morris et al were used to make comparisons with populations of healthy non-smoking men. ${ }^{34}$ Because volumes predicted by these equations frequently differ, comparisons were made with both. The refer-

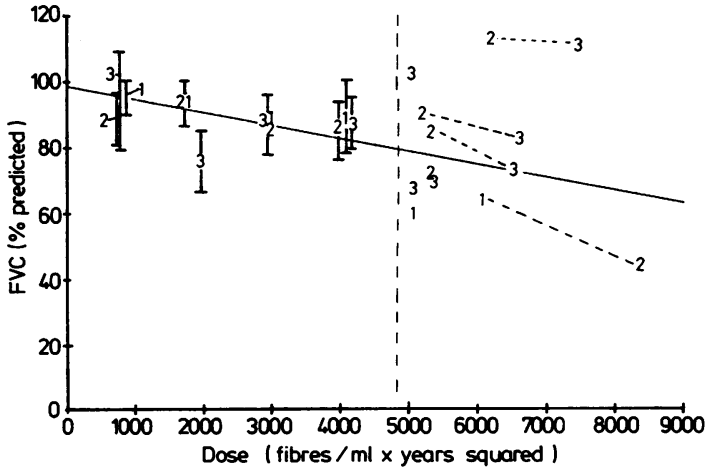

Fig 1 Latency dependence of FVC against dose. Numbers to left of dashed line are means (with $95 \%$ confidence limits) for dose intervals $1200 \mathrm{f} / \mathrm{ml} \times y^{2}$ wide; numbers to right refer to individuals. Latency intervals are: $1=20-24$ years; $2=25-29$ years; $3=30-34$ years. Regression line has been derived from "master cohort" in which each man contributes one value.

ence equation of Miller et al was used for diffusion tests. $^{5}$

STATISTICAL METHODS

The relations between PFT results and various explanatory variables were assessed by multiple linear regression with examination of residuals. Cox proportional hazard regression anaylsis was used to study PFT results as prognostic factors for mortality. ${ }^{6}$

\section{Results}

\section{LATENCY DEPENDENCE OF THE}

\section{DOSE-RESPONSE RELATIONS}

The relations between pulmonary function results and the explanatory variables age, height, smoking, and dose were explored by use of multiple linear regression. As noted in table 1 each man provided measurements in one or more latency periods and dose-response relations could be calculated separately for each interval. To test whether these relations differed among latency intervals, all the data were pooled and linear regression analyses were performed using "indicator variables" to specify to which interval each measurement belonged. The results indicated that the temporal terms did not add significantly to the fit of the models; the null hypothesis that the doseresponse relations were the same in all intervals was thus not rejected. This finding is illustrated for FVC in fig 1 in which, for ease of presentation, the data have been grouped in four dose categories.

Because the relation between dose and response was effectively independent of the time of assessment, 
Table 2 Regression coefficients from multiple linear regression analyses $(n=138)$. (Parentheses give estimates of the $95 \%$ confidence intervals)

\begin{tabular}{|c|c|c|c|c|c|c|}
\hline & Constant & Age & Height & Smoking & Dose & $R^{2}$ \\
\hline FVC (l) & $\begin{array}{l}-1 \cdot 77 \\
(-5 \cdot 3,+1 \cdot 8)\end{array}$ & $\begin{array}{l}-0.031 \\
(-0.044,-0.017)\end{array}$ & $\begin{array}{l}0.044 \\
(0.025,0.063)\end{array}$ & $\begin{array}{l}-0.20 \\
(-0.43,+0.03)\end{array}$ & $\begin{array}{l}-1.7 \times 10^{-4} \\
(-2.5,-1.0)\end{array}$ & 0.42 \\
\hline $\mathrm{FEV}_{1}(\mathrm{l})$ & $\begin{array}{l}0.63 \\
(-2 \cdot 4,+3 \cdot 6)\end{array}$ & $\begin{array}{l}-0.036 \\
(-0.048,-0.025)\end{array}$ & $\begin{array}{l}0.027 \\
(0.011,0.043)\end{array}$ & $\begin{array}{l}-0.32 \\
(-0.52,-0.13)\end{array}$ & $\begin{array}{l}-1 \cdot 1 \times 10^{-4} \\
(-1 \cdot 8,-0 \cdot 5)\end{array}$ & 0.44 \\
\hline $\mathrm{FEV}_{1} / \mathrm{FVC}$ & $\begin{array}{l}0.98 \\
(0.89,1.07)\end{array}$ & $\begin{array}{l}-0.0034 \\
(-0.0049,-0.0019)\end{array}$ & NS* $^{*}$ & $\begin{array}{l}-0.05 \\
(-0.077,-0.020)\end{array}$ & NS & $0 \cdot 17$ \\
\hline $\begin{array}{l}\text { FVC \%* } \\
\left(\text { Knudson et al }{ }^{3} \text { ) }\right. \\
\left.\text { (Morris et al } l^{4}\right)\end{array}$ & $\begin{array}{l}98 \cdot 6 \\
(92 \cdot 7,104 \cdot 4) \\
91 \cdot 4 \\
(86 \cdot 0,96 \cdot 7)\end{array}$ & $\begin{array}{l}\text { NS } \\
\text { NS }\end{array}$ & $\begin{array}{l}\text { NS } \\
\text { NS }\end{array}$ & $\begin{array}{l}-5 \cdot 0 \\
(-10 \cdot 4,+0 \cdot 4) \\
-4 \cdot 6 \\
(-9 \cdot 6,+0 \cdot 4)\end{array}$ & $\begin{array}{l}-4.0 \times 10^{-3} \\
(-5.7,-2.3) \\
-4.0 \times 10^{-3} \\
(-5.5,-2.4)\end{array}$ & $\begin{array}{l}0 \cdot 14 \\
0 \cdot 16\end{array}$ \\
\hline $\begin{array}{l}\mathrm{FEV}_{1} \% \\
\text { (Knudson et al) } \\
\text { (Morris et al) }\end{array}$ & $\begin{array}{l}97 \cdot 8 \\
(91 \cdot 4,104 \cdot 3) \\
101 \cdot 3 \\
(94 \cdot 7,107 \cdot 8)\end{array}$ & $\begin{array}{l}\text { NS } \\
\text { NS }\end{array}$ & $\begin{array}{l}\text { NS } \\
\text { NS }\end{array}$ & $\begin{array}{l}-10 \cdot 5 \\
(-16 \cdot 5,-4 \cdot 5) \\
-10 \cdot 8 \\
(-16 \cdot 9,-4 \cdot 8)\end{array}$ & $\begin{array}{l}-3.7 \times 10^{-3} \\
(-5.6,-1 \cdot 7) \\
-3.8 \times 10^{-3} \\
(-5.7,-1.9)\end{array}$ & $\begin{array}{l}0 \cdot 15 \\
0 \cdot 16\end{array}$ \\
\hline $\begin{array}{l}\text { FVC diff } \\
\text { (Knudson et al) } \\
\text { (Morris et al) }\end{array}$ & $\begin{array}{l}3.46 \\
(0 \cdot 35,6 \cdot 6) \\
-0 \cdot 42 \\
(-0.67,-0 \cdot 18)\end{array}$ & $\begin{array}{l}\text { NS } \\
\text { NS }\end{array}$ & $\begin{array}{l}-0.02 \\
(-0.038,0.003) \\
\text { NS }\end{array}$ & $\begin{array}{l}-0.20 \\
(-0.43,+0.02) \\
-0.20 \\
(-0.43,+0.03)\end{array}$ & $\begin{array}{l}-1.7 \times 10^{-4} \\
(-2.5,-1.0) \\
-1.7 \times 10^{-4} \\
(-2.4,-1.0)\end{array}$ & $\begin{array}{l}0 \cdot 16 \\
0 \cdot 14\end{array}$ \\
\hline $\begin{array}{l}\mathrm{FEV}_{1} \text { diff } \\
\text { (Knudson et al) } \\
\text { (Morris et al) }\end{array}$ & $\begin{array}{l}3.63 \\
(0.97,6 \cdot 3) \\
\text { NS }\end{array}$ & $\begin{array}{l}\text { NS } \\
\text { NS }\end{array}$ & $\begin{array}{l}-0.02 \\
(-0.036,-0.006) \\
\mathrm{NS}\end{array}$ & $\begin{array}{l}-0.33 \\
(-0.52,-0.13) \\
-0.32 \\
(-0.52,-0.13)\end{array}$ & $\begin{array}{l}-1.2 \times 10^{-4} \\
(-1.9,-0.6) \\
-1.1 \times 10^{-4} \\
(-1.7,-0.5)\end{array}$ & $\begin{array}{l}0.17 \\
0.14\end{array}$ \\
\hline
\end{tabular}

NS $=$ Not significant $(\mathrm{p}>0.05)$.

$*$ FVC $\%=$ Per cent of predicted from reference equations of Knudson et al ${ }^{3}$ and Morris et al. ${ }^{4}$

†FVC diff = FVC (observed-predicted): litres.

one set of measurements was chosen from each of the 138 workers who had data available and a pooled "master cohort" was created to provide the largest data set for subsequent analysis. Where possible, the values used were averages over the three consecutive years showing the least variability and with the greatest latency. Since there were relatively few measurements of diffusing capacity, the latency independence of diffusion could not be tested; it was assumed that the dose-response relations for diffusion would also be effectively independent of latency and the master cohort was also used for the analysis of this measure.

Three regression models were used to examine the relations between PFT results and the explanatory variables. In the first model the PFT value itself served as the dependent variable; in the two other analyses comparisons were made with the reference equations using proportional ( $\%$ predicted) and difference (observed-predicted) models. The results for FVC and FEV 1 are presented in table 2. Both FVC and $\mathrm{FEV}_{1}$ decreased significantly with increasing dose, about $4 \%$ of predicted per $1000 \mathrm{f} / \mathrm{ml} \times$ $y^{2}$, and because of the similarity of response their ratio, $\mathrm{FEV}_{1} / \mathrm{FVC}$, was independent of dose. Smokers had lower values of both FVC and $\mathrm{FEV}_{1}$ and the contributions of smoking and dose to decreased pulmonary function were additive. This is shown in table
3 , which shows that when the regression analyses were run separately for the smokers and non-smokers the dose coefficients were similar. Figure 2 shows the relation between FVC (observed-predicted) and dose; the considerable variability in the data is clearly shown.

The diffusion results are presented in table 4. Asbestos dose was associated with significantly lower

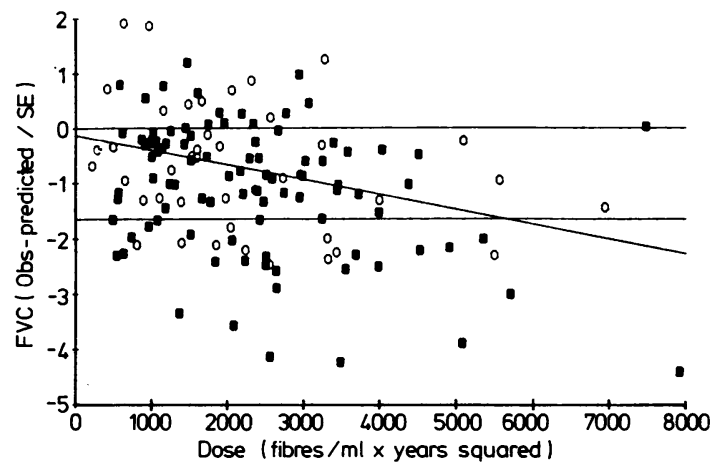

Fig 2 FVC (observed-predicted) against dose for master cohort. Unit for vertical axis is standard error of equation of Knudson et al $^{3}(600 \mathrm{ml})$ and horizontal line at $-1.65 \mathrm{SE}$ is lower limit of normal. Open circles refer to non-smokers and closed figures to smokers. 
Table 3 Relations between pulmonary function and dose for the smokers and non-smokers. ${ }^{*}$ (Numbers in parentheses are estimates of the $95 \%$ confidence intervals)

\begin{tabular}{|c|c|c|c|c|c|c|}
\hline & $F V C$ & $F E V_{1}$ & $F V C \%$ & $F E V_{1} \%$ & $T L C \dagger$ & DLCO† \\
\hline $\begin{array}{l}\text { Non-smokers } \\
(n=43) \\
\text { Smokers } \\
(n=95)\end{array}$ & $\begin{array}{c}-1.4 \times 10^{-4} \\
(-2.8,-0.1) \\
-1.9 \times 10^{-4} \\
(-2.8,-1.0)\end{array}$ & $\begin{array}{l}-1.1 \times 10^{-4} \\
(-2.2,0) \\
-1.2 \times 10^{-4} \\
(-2.0,-0.4)\end{array}$ & $\begin{array}{l}-3.3 \times 10^{-3} \\
(-6.1,-0.4) \\
-4.0 \times 10^{-3} \\
(-6.0,-2.0)\end{array}$ & $\begin{array}{l}-3.9 \times 10^{-3} \\
(-7.4,-0.5) \\
-3.5 \times 10^{-3} \\
(-5.9,-1.0)\end{array}$ & $\begin{array}{l}-0.8 \times 10^{-4} \\
(-2.9,+1.3) \\
-2.5 \times 10^{-4} \\
(-4.1,-0.9)\end{array}$ & $\begin{array}{l}+1.1 \times 10^{-4} \\
(-11.2,+13.4) \\
-9.9 \times 10^{-4} \\
(-18.5,-1.3)\end{array}$ \\
\hline
\end{tabular}

*Units of dose are fibres $/ \mathrm{ml} \times \mathrm{y}^{2}$.

+For TLC and DLCO the number of non-smokers was 26 and the number of smokers was 53.

Table 4 Regression coefficients from multiple linear regression analyses for diffusion

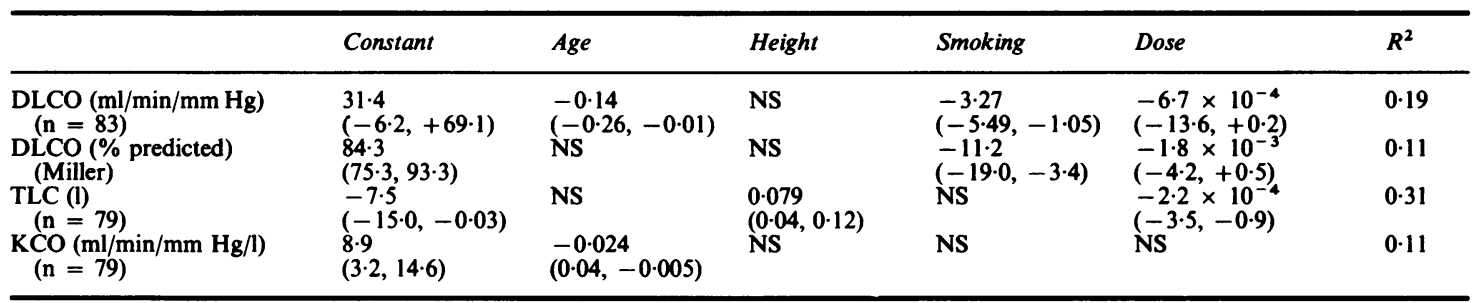

Table 5 Proportion of men with test results less than the lower limit of normal*

\begin{tabular}{|c|c|c|c|c|c|c|}
\hline $\begin{array}{l}\text { Dose interval } \\
\text { Mean dose }\end{array}$ & $\begin{array}{l}0-<1200 \\
840\end{array}$ & $\begin{array}{l}1200-<2400 \\
1800\end{array}$ & $\begin{array}{l}2400-<3600 \\
2950\end{array}$ & $\begin{array}{l}3600-<4800 \\
4090\end{array}$ & $\geqslant 4800$ & Test for trend \\
\hline $\begin{array}{l}\text { FVC: unadjusted } \\
\text { Knudson } \text { et }^{3} \mathbf{l}^{3} \\
\text { Morris et } \mathrm{al}^{4}\end{array}$ & $\begin{array}{r}7 / 37(19 \%) \\
11 / 37(30 \%)\end{array}$ & $\begin{array}{l}10 / 47(21 \%) \\
15 / 47(32 \%)\end{array}$ & $\begin{array}{l}12 / 35(34 \%) \\
17 / 35(49 \%)\end{array}$ & $\begin{array}{l}3 / 9(33 \%) \\
5 / 9(56 \%)\end{array}$ & $\begin{array}{l}6 / 10(60 \%) \\
7 / 10(70 \%)\end{array}$ & \\
\hline $\begin{array}{l}\text { FVC: smoking adjusted } \\
\text { Knudson et al } \\
\text { Morris et al }\end{array}$ & $\begin{array}{l}3 / 37(8 \%) \\
7 / 37(19 \%)\end{array}$ & $\begin{array}{r}9 / 47(19 \%) \\
12 / 47(26 \%)\end{array}$ & $\begin{array}{l}11 / 35(31 \%) \\
13 / 35(37 \%)\end{array}$ & $\begin{array}{l}3 / 9(33 \%) \\
5 / 9(56 \%)\end{array}$ & $\begin{array}{l}6 / 10(60 \%) \\
7 / 10(70 \%)\end{array}$ & $\begin{array}{l}\chi^{2}=14.2(\mathrm{p}<0.01) \\
\chi^{2}=12.9(\mathrm{p}<0.01)\end{array}$ \\
\hline $\begin{array}{l}\mathrm{FEV}_{1}: \text { unadjusted } \\
\text { Knudson et al } \\
\text { Morris et al }\end{array}$ & $\begin{array}{l}9 / 37(24 \%) \\
7 / 37(19 \%)\end{array}$ & $\begin{array}{l}8 / 47(17 \%) \\
7 / 47(15 \%)\end{array}$ & $\begin{array}{l}14 / 35(40 \%) \\
13 / 35(37 \%)\end{array}$ & $\begin{array}{l}4 / 9(44 \%) \\
3 / 9(33 \%)\end{array}$ & $\begin{array}{l}5 / 10(50 \%) \\
6 / 10(60 \%)\end{array}$ & \\
\hline $\begin{array}{l}\text { FEV }_{1} \text { : smoking adjusted } \\
\text { Knudson et al } \\
\text { Morris et al }\end{array}$ & $\begin{array}{l}6 / 37(16 \%) \\
4 / 37(11 \%)\end{array}$ & $\begin{array}{l}7 / 47(15 \%) \\
5 / 47(11 \%)\end{array}$ & $\begin{array}{l}12 / 35(34 \%) \\
10 / 35(29 \%)\end{array}$ & $\begin{array}{l}0 / 9(0 \%) \\
0 / 9(0 \%)\end{array}$ & $\begin{array}{l}5 / 10(50 \%) \\
3 / 10(30 \%)\end{array}$ & $\begin{array}{l}\chi^{2}=4.5(\mathrm{p}<0.05) \\
\chi^{2}=2.5(\mathrm{p}>0.1)\end{array}$ \\
\hline $\begin{array}{l}\text { DLCO: smoking adjusted } \\
\text { Miller et al }\end{array}$ & $4 / 12(33 \%)$ & $7 / 26(27 \%)$ & $8 / 27(30 \%)$ & $3 / 8(38 \%)$ & $5 / 10(50 \%)$ & $\chi^{2}=1.3(p>0.2)$ \\
\hline
\end{tabular}

*Units for dose are fibres $/ \mathrm{ml} \times \mathrm{y}^{2}$.

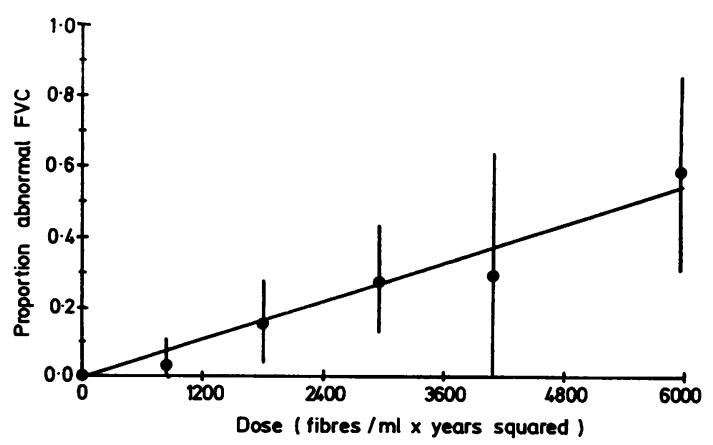

Fig 3 Proportion of abnormal values of FVC against dose, adjusted for smoking, and $5 \%$ abnormality rate in reference population. Error bars are estimates of $95 \%$ confidence limits. values for TLC and was of borderline statistical significance for decreased diffusing capacity. Smokers had significantly lower results for DLCO, but not for TLC. Once again, all dose-smoking interaction terms were non-significant.

\section{RELATION BETWEEN DOSE AND ABNORMAL PULMONARY FUNCTION}

The dose-response analysis presented in the previous section investigated the relation between dose and pulmonary function each measured on a continuous scale; an alternative approach is to classify each measurement as either normal or abnormal. One method of defining abnormality is by selecting as the lower limit of normal (LLN) the lower $95 \%$ confidence limit (or fifth centile) of measurements from healthy, nonsmoking reference populations such as those of Knudson et al or Morris et al. ${ }^{34}$ Thus for the present 
study the LLN was taken to be the predicted value minus $1.645 \times$ the standard error of the reference equation.

To assess the relation between dose and the prevalence of abnormalities the men were divided among dose categories $1200 \mathrm{f} / \mathrm{ml} \times \mathrm{y}^{2}$ wide. As a graphical analysis showed that the rate of abnormality in each interval was essentially independent of latency the master cohort was used for the detailed analysis. To adjust for any smoking differences among dose categories the average volumes lost by smokers, derived from the regression analyses of the previous section, were added to the measured values of the smokers: 0.21 for FVC; 0.321 for $\mathrm{FEV}_{1}$ and $3.3 \mathrm{ml} / \mathrm{min} / \mathrm{mm} \mathrm{Hg}$ for DLCO. The results are given in table 5 with, and without, the adjustment for smoking. The reference equations of Knudson et $\mathrm{l}^{3}$ and Morris $\mathrm{et} \mathrm{al}^{4}$ predict different LLN and this has an impact on the classification of abnormality.

For both FVC and FEV 1 the prevalence of abnormalities increased significantly with dose, but an effect could not be shown for DLCO. Tests for departure from a linear trend ${ }^{7}$ were non-significant. Finney presents an equation that may be used to adjust the observed proportions for the $5 \%$ abnormality rate in $\frac{\widehat{D}}{\mathrm{\alpha}}$

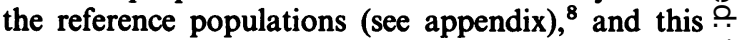
adjustment has been used in fig 3 which displays the $\overrightarrow{\overrightarrow{\mathrm{F}}}$ prevalence of abnormalities of FVC against dose.

\section{PULMONARY FUNCTION-RADIOGRAPHIC CORRELATIONS}

Radiographs, many of them serial, were available for $\stackrel{0}{\circ}$ all but two members of the master cohort and had os been interpreted according to the 1971 ILO $\vec{\circ}$ classification scheme by a NIOSH certified "B" $\overrightarrow{\vec{H}}$ reader before the gathering of the pulmonary func- $\vec{\omega}$ tion data. ${ }^{9}$ For the analysis of pulmonary function- $\stackrel{\circ}{\circ}$ radiographic correlations, the film closest in time $\frac{\mathbb{D}}{3}$ (within two to three years) to the pulmonary function test used in the master cohort analysis was selected. Men were grouped according to the scores for profusion of small irregular opacities and bilateral pleu- $\frac{\partial}{\circ}$ ral thickening and mean values for PFT were 0 computed. The results are presented in table 6 which $\stackrel{5}{\longrightarrow}$ shows that there was a trend for the average PFT $\bar{c}$ results to worsen as the radiographic appearance

Table 6 Relation between radiographic codes* and pulmonary function results

\begin{tabular}{|c|c|c|c|c|c|c|c|}
\hline $\begin{array}{l}\text { Radiographic } \\
\text { code }\end{array}$ & $0 / 0$ & $0 / 1$ & $1 / 0$ & $1 / 1$ & $\geqslant 1 / 2$ & $\begin{array}{l}\text { No pleural } \\
\text { thickening }\end{array}$ & $\begin{array}{l}\text { Pleural } \\
\text { thickening }\end{array}$ \\
\hline $\begin{array}{l}\text { No of men } \\
\text { FVC: }\end{array}$ & 75 & 13 & 9 & 31 & 8 & 101 & 35 \\
\hline $\begin{array}{l}\% \text { Predicted } \\
\text { No }<\text { LLN } \dagger\end{array}$ & $\begin{array}{l}84 \cdot 3 \\
(81 \cdot 0-87 \cdot 6) \\
12(16 \%)\end{array}$ & $\begin{array}{l}81 \cdot 0 \\
(73 \cdot 5-88 \cdot 5) \\
4(31 \%)\end{array}$ & $\begin{array}{l}70 \cdot 5 \\
(60 \cdot 6-80 \cdot 5) \\
4(44 \%)\end{array}$ & $\begin{array}{l}71 \cdot 9 \\
(66 \cdot 4-77 \cdot 5) \\
14(45 \%)\end{array}$ & $\begin{array}{l}63 \cdot 6 \\
(50 \cdot 3-76 \cdot 8) \\
4(50 \%)\end{array}$ & $\begin{array}{l}81.9 \\
(79 \cdot 0-84 \cdot 8) \\
21(21 \%)\end{array}$ & $\begin{array}{l}70 \cdot 8 \\
(65 \cdot 3-76 \cdot 3) \\
17(49 \%)\end{array}$ \\
\hline $\mathrm{FEV}_{1} / \mathrm{FVC}$ & $\begin{array}{l}0.76 \\
(0.73-0.78)\end{array}$ & $\begin{array}{l}0.77 \\
(0.75-0.79)\end{array}$ & $\begin{array}{l}0.75 \\
(0.66-0.84)\end{array}$ & $\begin{array}{l}0.73 \\
(0.69-0.76)\end{array}$ & $\begin{array}{l}0.77 \\
(0.70-0.83)\end{array}$ & $\begin{array}{l}0.75 \\
(0.73-0.77)\end{array}$ & $\begin{array}{l}0.76 \\
(0.73-0.79)\end{array}$ \\
\hline $\begin{array}{l}\text { DLCO } \\
\% \text { Predicted }\end{array}$ & $\begin{array}{l}76 \cdot 2(n=32) \\
(69 \cdot 8-82 \cdot 6)\end{array}$ & $\begin{array}{l}74 \cdot 7(n=8) \\
(54 \cdot 2-95 \cdot 3)\end{array}$ & $\begin{array}{l}75 \cdot 1(n=9) \\
(60 \cdot 8-89 \cdot 4)\end{array}$ & $\begin{array}{l}69 \cdot 2(n=26) \\
(62 \cdot 3-76 \cdot 1)\end{array}$ & $\begin{array}{l}55 \cdot 3(n=8) \\
(45 \cdot 0-65 \cdot 5)\end{array}$ & $\begin{array}{l}75 \cdot 0(n=54) \\
(69 \cdot 7-80 \cdot 4)\end{array}$ & $\begin{array}{l}65 \cdot 5(\mathrm{n}=29) \\
60 \cdot 0-71 \cdot 1)\end{array}$ \\
\hline No $<$ LLN & $12(38 \%)$ & $4(50 \%)$ & $4(44 \%)$ & $12(46 \%)$ & $7(88 \%)$ & $20(37 \%)$ & $18(62 \%)$ \\
\hline
\end{tabular}

* Radiographic codes are for small irregular opacities and bilateral pleural thickening.

tLLN is the lower limit of normal: 1.65 standard errors below the predicted value.

Table 7 Results of Cox regression mortality analysis for 115 men entering observation at 20-24 years latency

\begin{tabular}{|c|c|c|c|c|c|}
\hline \multirow[t]{2}{*}{ Variable } & \multicolumn{5}{|l|}{ Cause of death } \\
\hline & $\begin{array}{l}\text { All causes } \\
(n=40)\end{array}$ & $\begin{array}{l}\text { Mesothelioma } \\
(n=9)\end{array}$ & $\begin{array}{l}\text { Lung cancer } \\
(n=11)\end{array}$ & $\begin{array}{l}\text { All asbestos cancer } \\
(n=22)\end{array}$ & $\begin{array}{l}M I \\
(n=7)\end{array}$ \\
\hline $\begin{array}{l}\text { FVC: }(\beta) \dagger \\
\text { FEV } 1(\beta) \dagger \\
\text { FEV }_{1} / \text { FVC } \\
X \text { ray } \geqslant 1 / 1\end{array}$ & $\begin{array}{l}p<0.001(-0.50) \\
p_{N}<0.001(-0.50) \\
p<0.001\end{array}$ & $\begin{array}{l}\mathrm{p}<0.05(-0.57) \\
\mathrm{p}<0.10(-0.42) \\
\mathrm{NS} \\
\mathrm{NS}\end{array}$ & $\begin{array}{l}p<0.05(-0.57) \\
p<0.02(-0.60) \\
\text { NS } \\
p=0.05\end{array}$ & $\begin{array}{l}\mathrm{p}<0.005(-0.54) \\
\mathrm{p}<0.006(-0.46) \\
\mathrm{NS} \\
\mathrm{NS}\end{array}$ & $\begin{array}{l}\text { NS } \\
\text { NS } \\
\text { NS } \\
p<0.01\end{array}$ \\
\hline Multivariate models $\ddagger$ & $\begin{array}{l}\text { FVC }(p<0.04) \\
X \text { ray }(p<0.01)\end{array}$ & $\begin{array}{l}\text { Age }(p<0.04) \\
\text { FVC }(p<0.07)\end{array}$ & $\begin{array}{l}\text { Age }(\mathrm{p}<0.01) \\
\text { FVC }(\mathrm{p}<0.09)\end{array}$ & FVC $(p<0.01)$ & $X$ ray $(p<0.01)$ \\
\hline
\end{tabular}

MI = Myocardial infarction.

$\beta$ is the regression coefficient.

NS $=$ Not significant.

*Mesothelioma, lung, gastrointestinal.

TFVC and FEV ${ }_{1}$ are expressed in terms of a Z-score: observed-predicted/standard error of the reference equations of Knudson $e t$ al. ${ }^{3}$

fIn the multivariate models age, smoking, $x$ ray, and FVC were entered simultaneously. There was no correlation between FVC and age. 
worsened; there was, however, no association between $\mathrm{FEV}_{1} / \mathrm{FVC}$, an index of airways obstruction, and the radiographic codes. Men with bilateral pleural thickening had lower PFT results than men without, but this appears to be due to the correlation between pleural thickening and parenchymal opacities; among the 75 men who had a score of $0 / 0$ for small opacities there was no significant difference between the PFT results of the 12 men with bilateral pleural thickening and the 63 men without. In a complementary analysis men were grouped according to the results of their PFTs and mean values for the radiographic codings were computed; again PFT and radiographic results tended to worsen together. It was noted, however, that some men with normal results in one test technique had abnormalities in the other.

\section{PULMONARY FUNCTION-MORTALITY}

CORRELATIONS

One hundred and fifteen men had pulmonary function testing at 20-24 years latency. A Cox regression analysis was used to investigate whether the test results were prognostic factors for subsequent mortality. The results for FVC, $\mathrm{FEV}_{1}$, and FEV/FVC were expressed as Z-scores (observed-predicted/ standard error of the reference equation of Knudson et $\dot{a} l^{3}$ ) and tested for association with mortality in both univariate and multivariate models that also included age, smoking, and $x$ ray $(\geqslant 1 / 1)$ as predictor variables. Table 7 gives the results.

Decreased FVC and $\mathrm{FEV}_{1}$ were significantly associated with all cause mortality and with death from asbestos associated cancers. FVC and FEV $_{1}$ are highly correlated and the regression coefficients, $\beta$, are similar. In the Cox model relative risk is given approximately by $\mathrm{e}^{\beta \mathrm{Z}}$; taking $\beta=-0.5$ (and with the standard error for FVC being $600 \mathrm{ml}$ ) then the relative risk of death for individuals with FVC $600 \mathrm{ml}$ less than predicted is $\mathrm{e}^{0.5}=1.6$ and for individuals with FVC at the lower limit of normal it is $\mathrm{e}^{0.5 \times 1.65}=$ 2.3. The presence or absence of small irregular opacities on the chest radiograph provided no additional prognostic information beyond that contained in FVC except for death from myocardial infarction.

\section{Discussion}

The aim of this study was to determine whether asbestos "dose," a new measure of exposure incorporating information about both dust concentrations and latency, would prove useful in modelling the risk and extent of pulmonary function abnormalities in a cohort of asbestos cement workers. An earlier study of the cohort had found this parameter to be useful in describing the risk of small irregular opacities on the chest radiograph ${ }^{1}$ and the present analysis indicates that it is also valuable for functional abnormalities. It was determined that the dose-response relations were independent of the time of assessment over the time interval 20-34 years from first exposure and so this one parameter, dose, may be used to model disease risk, rather than the two, cumulative exposure and time, that would otherwise be required.

The analysis was performed with data from 138 $(77 \%)$ of the 180 men who met the criteria for entry to the study. The others had left employment before the initiation of routine pulmonary function testing in 1970 and had neither returned for follow up nor filed claims for workers' compensation. It would be expected that, because of the widespread publicity given to asbestos disease in Ontario, most former employees with significant disease would have established compensation claims; the lung function of those lost to follow up is thus likely, on average, to be no worse than that of workers with similar dosages who were included in the analysis. Since the dosages of those lost to follow up were, on average, less than those of the men included in the analysis, the effect of any bias due to selective entry into the study would be to underestimate the mean test results at the lower end of the dose range and to underestimate the slope of the dose-response curves. Since the intercepts for FVC and $\mathrm{FEV}_{1}$ (\% predicted) in the multiple regression analyses are close to $100 \%$, this bias is unlikely to be large.

Workers at this factory were exposed to dusts of chrysotile and crocidolite asbestos, silica, and cement. Silica is generally regarded as producing little functional abnormality unless silicosis progresses beyond the simple nodular stage. ${ }^{1011}$ Irwig and Rocks found that silicosis had no effect on FVC in gold miners but that there was a relation between exposure to dust in gold mines and symptoms and lung function tests indicative of chronic obstructive lung disease. ${ }^{12}$ Similarly, Kalacic found no decrease in FVC among cement workers, but did find changes in the $\mathrm{FEV}_{1} / \mathrm{FVC}$ ratio suggestive of obstructive impairment. ${ }^{1314}$ Since the exposure related changes in the present study were of a restrictive rather than an obstructive pattern, assessment of the asbestos effect is unlikely to be substantially confounded by exposure to the other components of the dust cloud. Conceivably the clearance of asbestos might be altered by concurrent exposure to the other dusts, but this possibility could not be assessed.

The pattern of abnormalities observed in this cohort was similar to that generally described among asbestos workers-namely, a dose related reduction in vital capacity, total lung capacity, and carbon monoxide diffusing capacity. ${ }^{10}$ There was no evidence of obstructive disease beyond that attributable to smoking. Begin and colleagues have presented evi- 
dence of small airways obstruction among nonsmoking employees of the Quebec asbestos mining industry, but detection of these changes required an advanced physiological assessment and they were not detectable by routine spirometry. ${ }^{15}$

Two different models were used to explore the relation between asbestos dose and abnormality of lung volumes. In the proportional model asbestos dosage was presumed to cause a loss in the "per cent of predicted" volume. Since the predicted volume depends on the age and height of the worker, the actual volume lost when the per cent predicted declines may differ among workers accumulating the same dose. In the difference model asbestos dosage produces a loss of volume that is independent of the predicted volume. Intuitively, it would seem that a given dosage of asbestos should not produce the same loss of volume among men differing in size and age and that the proportional model should be preferable; nevertheless in the present analysis both models fit the data equally well and one could not be selected as preferable to the other

The effects of smoking and asbestos were independent and additive in this cohort. Abnormalities attributed to smoking were similar to those reported in the smoking health effects reports. Krumholz and Hedrick studied a group of middle aged executives with a mean age of 47 and a mean height of $179 \mathrm{~cm} .{ }^{16}$ Smokers had lower mean values for VC $(300 \mathrm{ml})$, FEV $_{1}(375 \mathrm{ml})$, and DLCO $(5 \mathrm{ml} / \mathrm{min} / \mathrm{mm} \mathrm{Hg})$ than non-smokers. Edelman and colleagues studied another group of white collar workers. ${ }^{17}$ For men aged 50 and $176 \mathrm{~cm}$ in height, smokers had lower values for VC $(200 \mathrm{ml})$ and $\mathrm{FEV}_{1}(170 \mathrm{ml})$. In the present study in which the mean age was 58 and the mean height $174 \mathrm{~cm}$ the differences were found to be $200 \mathrm{ml}$ for FVC, $320 \mathrm{ml}$ for $\mathrm{FEV}_{1}$, and $3.3 \mathrm{ml} / \mathrm{min} / \mathrm{mm} \mathrm{Hg}$ for DLCO. When an estimate was made of pack-years (P-Y) consumption for each man, the loss in FEV was found to be $8 \mathrm{ml} / \mathrm{P}-\mathrm{Y}$. This compares well with the $8 \mathrm{ml} / \mathrm{P}-\mathrm{Y}$ reported by Speizer et al ${ }^{18}$ and the $11 \mathrm{ml} / \mathrm{P}-\mathrm{Y}$ among current smokers and $7 \mathrm{ml} / \mathrm{P}-\mathrm{Y}$ among ex-smokers reported by Beck and colleagues. ${ }^{19}$

In the present analysis the data were compatible with linear asbestos dose-response relations. When account was taken of smoking habit, a loss of FVC of $170 \mathrm{ml}$ (or $4 \%$ of predicted) per $1000 \mathrm{f} / \mathrm{ml} \times \mathrm{y}^{2}$ was attributable to asbestos exposure. Significant dose related trends were found for the prevalence of abnormalities of FVC and $F_{E V}$. For carbon monoxide diffusing capacity, a dose-response relation was found only among the smokers (table 3 ) and the prevalence of abnormalities did not vary significantly with dose (table 5). Several other studies have failed to find clear trends in diffusing capacity with exposure. ${ }^{2021}$ One of the hallmarks of advanced disease is a decreased $\overline{2}$ diffusing capacity, ${ }^{10}$ and it may be that in epi- $\frac{T}{8}$ demiological studies a trend is obscured by uncer- ?. tainties in measurement and exposure assignment.

Many epidemiological studies have shown that $\stackrel{\vec{P}}{+}$ death rates among asbestos exposed workforces vary with exposure. For most workers quantitative esti- $\frac{\bar{F}}{\bar{D}}$ mates of asbestos exposure will not be available; in $\frac{\sigma}{\vec{\sigma}}$ this circumstance it might be helpful if the results of $\unrhd$ clinical tests could be used as surrogates for exposure estimates and if prognostic assessments could be $\vec{\circ}$ made according to the results. It was shown previously that in this cohort of asbestos cement workers $\vec{\omega}$ the profusion of small irregular opacities on the chest $\stackrel{\Omega}{\Omega}$ radiograph was a prognostic factor. ${ }^{9}$ In the present $\stackrel{\mathbb{D}}{\stackrel{D}{~}}$ analysis pulmonary function was also found to have prognostic value with individuals having an FVC at the lower limit of normal estimated to have a risk of death raised twofold compared with individuals ${ }^{\circ}$ whose results were the same as those predicted by the reference equation of Knudson. ${ }^{3}$ Since radiographic $\stackrel{5}{\supset}$ and PFT results are correlated, the question of $\vec{c}$ whether any additional information could be ob- $\frac{\varsigma}{5}$

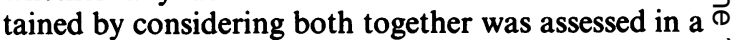
multivariate Cox regression model. Only for the case $\vec{\bullet}$ of death from myocardial infarction did the radiographic result provide prognostic information beyond $\square$ that contained in FVC, and for this cause of death there was no association between FVC and risk. The association between radiographic abnormality and death from infarction in this cohort is possibly due to $\stackrel{\circ}{\mathcal{Q}}$

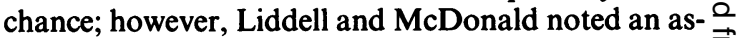
sociation between the presence of small opacities and $\overrightarrow{0}$ the risk of death from diseases of the heart among Quebec asbestos workers so the association may be $\mathrm{a}$ true one. ${ }^{22}$

In conclusion, this study found that the use of residence time weighted exposure as a measure of asbes- 3 tos dose provided estimates of the dose-response $\overline{3}$ relations of various pulmonary function tests that were independent of latency over the interval 20-34\% years from first exposure. An earlier study of the same cohort found that the same dose measure could be $\frac{\text { 의 }}{2}$ used to model the risk of radiographic abnormalities $>$ and might be useful for modelling mesothelioma을 rates. It thus appears that this one parameter, dose, $\tilde{N}$ could replace the two, cumulative exposure and time, - o which are otherwise required to model dose-response $N$ relations in the pneumoconioses. Verification of this hypothesis in other cohorts exposed to fibrogenic dusts would be of interest.

\section{Appendix}

(1) The formula used to calculate dose: 
$\mathrm{D}(\mathrm{T})=\sum_{\mathrm{i}=1}^{\mathrm{T}} \mathrm{C}\left(\mathrm{t}_{\mathrm{i}}\right)\left(\mathrm{T}-\mathrm{t}_{\mathrm{i}}\right)$

Where $D(T)$ is the dose in the year $T$ and $C\left(t_{i}\right)$ is the average exposure in the year $t_{i}$.

(2) The adjustment of prevalence for background occurrence:

$P=\frac{P^{*}-C}{1-C}$

Where $\mathrm{P}^{*}$ is the observed prevalence at dose $\mathrm{D}$

$\mathrm{C}$ is the prevalence in an unexposed population (here $5 \%$ ) and

$\mathbf{P}$ is the adjusted prevalence.

\section{References}

${ }^{1}$ Finkelstein MM. A study of dose-response relationships for asbestos associated disease. Br J Ind Med 1985;42:319-25.

${ }^{2}$ Finkelstein MM. Asbestosis in long-term employees of an Ontario asbestos-cement factory. Am Rev Respir Dis 1982;125:496-501.

${ }^{3}$ Knudson RJ, Slatin RC, Lebowitz MD, Burrows B. The maximal expiratory flow-volume curve. Am Rev Respir Dis 1976;113:587-600.

${ }^{4}$ Morris JF, Koski A, Johnson LC. Spirometric standards for healthy nonsmoking adults. Am Rev Respir Dis 1971;103:57-67.

${ }^{5}$ Miller A, Thornton JC, Warshaw R, et al. Single breath diffusing capacity in a representative sample of the population of Michigan, a large industrial state. Am Rev Respir Dis 1983;127:270-7.

${ }^{6}$ Harrell F. The PHGLM procedure. (SAS supplemental library users' guide.) Cary, North Carolina: SAS Institute Inc, 1980.
${ }^{7}$ Armitage P. Statistical methods in medical research. Oxford: Blackwell Scientific Publications, 1971.

${ }^{8}$ Finney DJ. Probit analysis. 3rd ed. Cambridge: Cambridge University Press, 1971.

${ }^{9}$ Finkelstein MM, Vingilis JJ. Radiographic abnormalities among asbestos cement workers: an exposure-response study. Am Rev Respir Dis 1984;129:17-22.

${ }^{10}$ Morgan WKC, Seaton A. Occupational lung disease. 2nd ed. Philadelphia: WB Saunders, 1984

${ }^{11}$ Parkes WR. Occupational lung disorders. 2nd ed. London: Butterworths, 1982.

${ }^{12}$ Irwig LM, Rocks P. Lung function and respiratory symptoms in silicotic and nonsilicotic gold miners. Am Rev Respir Dis 1978;117:429-35.

${ }^{13}$ Kalacic I. Chronic nonspecific lung disease in cement workers. Arch Environ Health 1973;26:78-83.

${ }^{14} \mathrm{Kalacic}$ I. Ventilatory lung function in cement workers. Arch Environ Health 1973;26:84-5.

${ }^{15}$ Begin R, Cantin A, Berthiaume Y, et al. Airway function in lifetime-nonsmoking older asbestos workers. Am J Med 1983;75:631-8.

${ }^{16}$ Krumholz RA, Hedrick EC. Pulmonary function differences in normal smoking and nonsmoking, middle-aged, white-collar workers. Am Rev Respir Dis 1973;107:225-9.

${ }^{17}$ Edelman NH, Mittman C, Norris AH, Cohen BH, Shock NW. The effects of cigarette smoking upon spirometric performance of community dwelling men. Am Rev Respir Dis 1966;94:421-9.

${ }^{18}$ Speizer FE, Dockry DW, Ferris BG, Ware JH, Louis T. A simple model for the loss of pulmonary function associated with cigarette smoking. Am Rev Respir Dis 1985;131:A177.

${ }^{19}$ Beck GJ, Doyle CA, Schachter EN. Smoking and lung function. Am Rev Respir Dis 1981;123:149-55.

${ }^{20}$ Becklake MR, Fournier-Massey G, Rossiter CE, McDonald JC. Lung function in chrysotile asbestos mine and mill workers of Quebec. Arch Environ Health 1972;24:401-9.

${ }^{21}$ Weill H, Ziskind MM, Waggenspack C, Rossiter CE. Lung function consequences of dust exposure in asbestos cement manufacturing plants. Arch Environ Health 1975;30:88-97.

${ }^{22}$ Liddell FDK, McDonald JC. Radiological findings as predictors of mortality in Quebec asbestos workers. $\mathrm{Br} J$ Ind Med 1980;37:257-67. 